\title{
Effect of Untreated Water Flow Rate at Certain Temperature on the Discharge of Treated Water
}

\author{
Muhammad Arshad Ullah", *, Muhammad Aslam, Raheel Babar ${ }^{2}$ \\ ${ }^{1}$ Land Resources Research Institute, National Agricultural Research Centre, Islamabad, Pakistan \\ ${ }^{2}$ Forestry, Range, Watershed and Wildlife Management, Baluchistan Agriculture College, Quetta, Pakistan

\section{Email address:} \\ arshadullah1965@gmail.com (M. A. Ullah), maslam@yahoo.com (M. Aslam), raheelbabarrao@yahoo.com (R. Babar) \\ ${ }^{*}$ Corresponding author
}

\section{To cite this article:}

Muhammad Arshad Ullah, Muhammad Aslam, Raheel Babar. Effect of Untreated Water Flow Rate at Certain Temperature on the Discharge of Treated Water. International Journal of Homeopathy \& Natural Medicines. Vol. 5, No. 1, 2019, pp. 8-11.

doi: $10.11648 /$ j.ijhnm.20190501.12

Received: November 22, 2018; Accepted: March 19, 2019; Published: April 26, 2019

\begin{abstract}
The origin and continuation of mankind is based on water. Water is one of the most abundant resources on earth, covering three-fourths of the planet's surface. Water is one of the earth's most abundant resources, covering about threequarters of the planet's surface. The reason for this apparent contradiction is, of course, that $-97.5 \%$ of the earth's water is salt water in the oceans and only $2.5 \%$ is fresh water in ground water, lakes and rivers and this supplies most human and animal needs. It would be feasible to address the water-shortage problem with seawater desalination; however, the separation of salts from seawater requires large amounts of energy which, when produced from fossil fuels, can cause harm to the environment. The discharge from desalination plants is almost entirely water, and .01 percent is salt. Desalination is a process that extracts minerals from saline water. Solar-powered desalination technologies can be used to treat non-traditional water sources to increase water supplies in rural, arid areas. Water is the basis of life, the origin of human endurance, and the prime material base to guarantee the economy significant development of a country. This solar desalination technique explains the diminutive and extensive-period feasibility of via solar energy as a system to influence desalination. Seawater and briny water were considered, as well as liquid waste. This protocol summarizes that solar desalination expenditure remains lower to exchange saline water into clean water. Water scarceness is a rising dilemma for large regions of the world. Access to safe, fresh and pure clean drinking water is one of the most important and prime troubles in different parts of the world. Among many of water cleansing technologies solar desalination/distillation/purification is one of the most sustainable and striking method engaged to congregate the supply of clean and pure drinkable water in remote areas at a very sound cost. Six types of dripper having discharge $3-8 \mathrm{lh}^{-1}$ were installed one by one and measured discharge and volume of clean water indicated that at $6 \mathrm{lh}^{-1}$ untreated water discharge have maximum evaporation and volume of clean water was $19.2 \mathrm{~h} \mathrm{~h}^{-1}$ at same temperature and radiations. Now strategy was developed that when increased the temperature the intake discharge of untreated water must be increased and salt drained water two times more than treated water.
\end{abstract}

Keywords: Solar Desalination Panels, Reverse Osmosis, Brackish Water and Desalinized Water

\section{Introduction}

The reduction of groundwater is an apparition offered for many parts of the world that depend on the un managed utilization of groundwater. Groundwater irrigation has been a key strength after the remarkable raise in food productivity in South Asia. The consistency and suitability of groundwater exploit and the supplementary water it brought have ended it a vital part of the region's green revolution since the 1970s. However, groundwater is also the world's 'mainly mined reserve' [1-2]. Over recent decades, groundwater use has grown exponentially in scale and passion in many places, principal to aquifer depletion and groundwater pollution [35].

The use of solar irradiation for management of chemically and biologically contaminated water is not an innovative drift [6-7]. With increasing global population, the fissure among 
the supply and demand for water is widening and is reaching such disquieting levels that in some part of the world, it is pretense a menace to human survival [8]. The remaining percentage is made up of brackish water, vaguely salty water found as surface water in estuaries and as groundwater in salty aquifers. The need for fresh water is at the apex of the international schema of decisive problems, at least as definitely as climate change. India as a country has $16 \%$ of the world's population and $4 \%$ of its fresh water resources [9].

The fresh water scarcity is a rising setback all over the world because only $1 \%$ of earth's water is freshwater available for human to drink. The US geological survey established that $96.5 \%$ of earth's water is sited in seas and oceans and $1.7 \%$ of earth's water is positioned in the ice caps [10]. Water dearth tends to arise in regions with high received solar energy [11]. Such areas are gaining population faster than the rest of the country in the United States. Southwestern states, the most dry and high irradiance regions in the nation-have constantly detained high population growth rates [12]. The multiple effects of drought and growth advocate these states face considerable challenges meeting current and future water needs [13]. Consequently, drinking water of acceptable quality has become a scarce commodity. The total global water reserves are approximately 1.4 billion $\mathrm{km}^{3}$, of which around $97.5 \%$ is in the oceans and the remaining $2.5 \%$ is fresh water present in the atmosphere, ice, mountains and ground water. Of the total, only $0.014 \%$ is directly available for human beings and other organisms [14].

Water desalination with solar utilization is ever more suitable an aggressive way out for supplying drinking water in many countries around the world. The desalination of brackish water has been documented as one of the most sustainable and new water resource alternate. It plays a decisive task in the socio-economic progress for many communities and industrial sectors. Presently there are above 14,000 desalination plants in operation worldwide providing several billion gallons of water per day. Large scale conventional heat and power plants are installed are in the Middle East and Gulf region. However, since they are operated using fossil fuels, they are becoming costly to operate and they produce the pollution and greenhouse gas emissions that are increasingly injurious to the environment. Furthermore such plants are not cost-effectively workable in distant areas, still in coastal regions where seawater is plentiful. Many areas often experience a shortage of fossil fuels and insufficient and defective electricity supply. The combination of renewable energy resources in desalination and water purification is becoming more viable as costs of conventional systems increase, commitments to reduce greenhouse gas emissions are implemented and targets for exploiting renewable energy are set. Thus, solar energy could provide a sustainable alternative to drive the desalination plants, especially in countries which lie on the solar belt such as Africa, the Middle East, India, Pakistan and China. Stipulation of harmless drinking water is a crucial for the life and consequences in socio-economic development. Fresh water assets are speedily decreasing owing to raise in the population and mismanagement and the promising climate changes are more accelerating the procedure of water scarcity. This is dire need of the time to purify saline water into drinkable principally in the coastal areas which have lowly right to use the safe drinking water and ground water is often brackish. The coastal population is prone to a number of health problems because of using insecure water. Distillation is one of many processes that can be used for water purification. This requires an energy input, as heat, solar radiation can be the source of energy. In this process, water is evaporated, thus separating water vapor from dissolved matter, which is condensed as pure water. Solar power desalination and air water technologies are having very low maintenance and operation cost, easy installation and operation, no skilled labor requirement, low initial investment as compared to reverse osmosis, no high tech exchange parts like batteries, filters or membranes, and independent drinking water supply for individual families. Most of our earth surface is enclosed by water; though, below $1 \%$ of total accessible water is fresh water which frequently exists in lakes, rivers and underground. Once more, in relation to one-third of that potential fresh water can only be used for human needs due to mixed factors. Approximately 1.1 billion People in this world have inadequate access to safe drinking water. Approximately 26 countries do not have sufficient water to continue agriculture and economic developments. Arid and semiarid countries have serious intermittent drought considering at least $80 \%$. A third of Africans and most of Middle-East people survive without adequate water [15]. Solar distillation is a method where solar energy is used to generate fresh water from saline or brackish water for drinking, domestic and other purposes. There are several distillation methods developed for water desalination technology which vary in minimalism, cost and applications. In the last decades, many researchers have been conducted to minimize the cost of this process, and several methods have been developed. Among these methods, solar distillation occurs as one of the best practical and the most economical, especially for mass production of fresh water from high saline water like seawater [16].

\section{Experiment Procedure/Design}

The following are the description of solar powered water desalination system AROCELL solar water purifies Australian technology. It only use sun energy, there are no moving parts, no electronics. It is robust and easy to setup, low maintenance and very low in operating cost because the water purifier only need solar energy. The feed water is supplied by gravity or pressure pump CAROCELL direct solar powered desalination technology, working at ambient temperature, heats the input water causing vapors condensation change precluding all bacteria and pathogens, therefore eliminating all water borne diseases Exposure to ultra violet light and extreme heat from solar energy through the advanced composite panels enhances the germ killing 
process. CAROCELL's increased efficiency (65\% with peak efficiencies above $80 \%$ ) over other solar distillation products $(30-40 \%)$ is a combination of the proprietary materials used to dramatically increase the temperature of the feed water on the solar collector which enhances the evaporation/condensation processes inside the panel. Additionally, this sophisticated geometrical design has easy maintenance, optimum performance and a self-controlling natural convection loop enabling widely superior energy recovery [17]. The study was conducted to gather data of clean water volume per day along with temperature and solar irradiation. The out flow rate of clean water measured at constant in flow of untreated water along with temperature at 8.0 am to 4 pm daily. It was observed that inflow of untreated water needs to be adjusted along with temperature variation to increase the clean water volume per day. Now strategy was developed that when increased the temperature the intake discharge of untreated water must be increased and salt drained water two times more than treated water. This strategy was applied for further data generation. Temperature data were used of agro met station of CAEWRI, NARC, Islamabad.

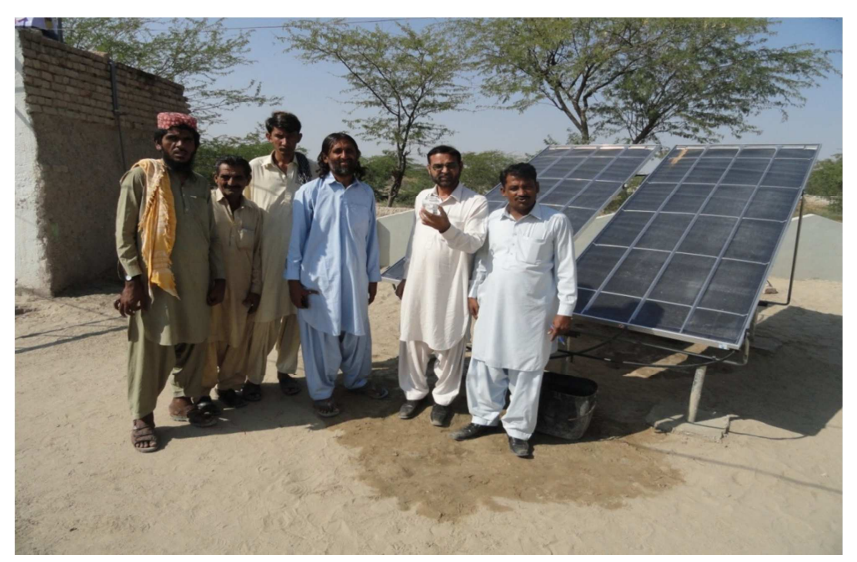

Figure 1. Train the farmers for operation and maintenance of solar desalination system.

\section{Results and Discussions}

Reverse Osmosis (RO) is the one and only one regularly used domestic filtration system that removes even all the impurities. RO is required if the Total Dissolved Solids
(TDS) exceeds a certain value. The use of solar irradiation for treatment of chemically and biologically contaminated water is not a new trend [17]. Pure water is the basic necessary for all living organism. Now days, the availability of clean water resource is a major issue for mankind. A lack of infrastructure for water storage and distribution is also a factor in the developing world. More than $71 \%$ of the earth surface is covered with the water, but only $1 \%$ clean drinkable water is available with the international standards [18].

The solar desalination systems were installed in these areas where saline water ranges from $(3,000-20,000)$ PPM for evaluation and their field performance. The study was conducted to gather data of clean water volume per day along with temperature and solar irradiation. The out flow rate of clean water measured at constant in flow of untreated water along with temperature at 8.0 am to $4 \mathrm{pm}$ daily. Data indicated in Table 1 showed that the discharge volume of cleaning water was increasing as well as the temperature of the sunlight hours increasing. It was observed that inflow of untreated water needs to be adjusted along with temperature variation to increase the clean water volume per day. Six types of dripper having discharge $3-8 \mathrm{lh}^{-1}$ were installed one by one and the data of measured discharge and volume of clean water indicated that at $6 \mathrm{lh}^{-1}$ untreated water discharge have maximum evaporation and volume of clean water was $19.2 \mathrm{lh}^{-1}$ followed by $7 \mathrm{lh}^{-1}$ untreated water discharge produced clean water was $18.0 \mathrm{lh}^{-1}$ at same temperature and radiations (Table 1). Similarly results were also produced by the findings of Muhammad et al., [17]. This experiment resulted that 7 lh-1 intake discharges gained the highest position in attaining the clean water during summer season. The efficiency of desalinization rate was reduced to 8.8 10.4 liter in winter due to less sunshine hours as well as low temperature as comparing to summer [19]. Ullah et al., [20] concluded that the purification of saline water into drinkable water depends upon the intake saline water capacity of each desalinization solar unit. The desalinization solar units performed better results if intake water adjustment was done (a)6 liters/hr/panel). The brackish water converts into fit water having very minute salts at Goth Bashirullah, Gadani, Lasbella, Baluchistan [21].

Table 1. Effect of untreated water flow rate at certain temperature on the discharge of treated water recorded at NARC Islamabad.

\begin{tabular}{|c|c|c|c|c|c|c|}
\hline \multicolumn{2}{|c|}{ Temperature $\left({ }^{\circ} \mathrm{C}\right)$} & \multicolumn{3}{|c|}{ Discharge $\left(\mathrm{Ih}^{-1}\right)$} & \multirow{2}{*}{$\begin{array}{l}\text { Solar Irradiation } \\
\text { Islamabad }\left(\mathrm{KWhm}^{-2}\right)\end{array}$} & \multirow{2}{*}{$\begin{array}{l}\text { Treated Water } \\
\left(\text { lday }^{-1}\right) \\
\end{array}$} \\
\hline Min. & Max. & Untreated & Treated & Drain & & \\
\hline \multirow[t]{6}{*}{15.7} & 27.5 & 10 & 1.90 & 8.10 & 174 & 15.2 \\
\hline & & 9 & 2.10 & 6.90 & 174 & 16.8 \\
\hline & & 8 & 2.15 & 5.85 & 174 & 17.2 \\
\hline & & 7 & 2.25 & 4.75 & 174 & 18.0 \\
\hline & & 6 & 2.40 & 3.60 & 174 & $19.2^{*}$ \\
\hline & & 5 & 2.20 & 2.80 & 174 & 17.6 \\
\hline
\end{tabular}

\section{Conclusion}

This Protocol concluded that $19.2 \mathrm{lh}^{-1}$ clean water was attained in a day by one solar desalination unit. This volume was increased as well as the temperature was increase. Six types of dripper having discharge $3-8 \mathrm{lh}^{-1}$ were installed one by one and the data of measured discharge and volume of 
clean water indicated that at $6 \mathrm{lh}^{-1}$ untreated water discharge have maximum evaporation and volume of clean water was $19.2 \mathrm{lh}^{-1}$ followed by $7 \mathrm{lh}^{-1}$ untreated water discharge produced clean water was $18.0 \mathrm{lh}^{-1}$ at same temperature and radiations.

\section{References}

[1] UNESCO, 2003. World Water Assessment Programme. Water for People, Water for Life. A Joint Report by the Twenty-three UN Agencies Concerned with Freshwater. UNESCO, Paris) Pp; 576.

[2] Mukherjee A., Dipankar S, Charles F. Harveyc, Richard G. Taylor, K. M. A., Soumendra N. B. 2015. Ground water systems of the Indian subcontinent. Journal of Hydrology: Regional Studies 4; 1-14.

[3] Giordano M. 2009. Global groundwater? Issues and solutions. Annual Review of Environment and Resources 34): 153-178.

[4] Wada Y., Ludovicus P. H. van Beek, Cheryl M. van Kempen, Josef W. T. M. Reckman, Slavek Vasak, and Marc F. P. Bierkens, 2010. Global depletion of ground- water resources. Geophysical Research Letters 37; 1-5.

[5] Kulkarni H., Mihir S., Shankar P. S. V., 2015. Shaping the contours of groundwater governance in India. Journal of Hydrology: Regional Studies 4; 172-192.

[6] Sinton LW, CH Hall, PA Lynch, RJ Davies Colley, 2002. Sunlight inactivation of fecal indicator bacteria and bacteriophages from waste stabilization pond effluent in fresh and saline waters. Appl Environ Microbiol 68: 1122-1131.

[7] Hal Crow, 2007. Supporting Public Resource Management in Balochistan. Basin-wide Water Resources Availability and use. Asian Development Bank: Supporting Public Resource Management in Balochistan.

[8] Li Y. and K. Tian, 2009. Application of vacuum membrane distillation in water treatment. Journal of Sustainable Development 2 (3): 183-186.

[9] Abraham T. and A. Luthra, 2011. Socio-economic and technical assessment of photovoltaic powered membrane desalination processes for India. Desalination. 268 (1-3): 238-248.

[10] Pangarkar B. L., P. V. Thorat, S. B. Parjane, and R. M. Abhang, 2010. Performance evaluation of vacuum membrane distillation for desalination by using a flat sheet membrane. Desalination and Water Treatment 21 (1-3): 328-334.

[11] Brutsaert, 2005. Wilfried, Hydrology: An Introduction. Cambridge; New York: Cambridge University Press. Print.

[12] Mackun, P. J., S. Wilson, T. R. Fischetti, and J. Goworowska, 2011. Population Distribution and Change: 2000 to 2010. Washington, D. C.: U.S. Dept. of Commerce, Economics and Statistics Administration, U.S. Census Bureau, Print.

[13] Scott, C. A. and M. J. Pasqualetti, 2010. Energy and water resources scarcity: Critical infrastructure for growth and economic development in Arizona and Sonora. Natural Resources Journal, 50 (3), 645-682.

[14] Al Kharabsheh S and Yogi Goswami D., 2003. Analysis of an innovative water desalination system using low-grade solar heat. Desalination 156 (1-3): 323-332.

[15] Bouchekima, 2003. Solar desalination plant for small size use in remote arid areas of South Algeria for the production of drinking water. Desalination 156 (1-3); 353-354.

[16] Saidur, R., Elcevvadi, E. T., Mekhilef, S., Safari, A. and Mohammed, H. A. 2011. An overview of different distillation methods for small scale applications. Renewable \& Sustainable Energy Reviews 15: 4756-4764.

[17] Muhammad A. U., A. Ali., M. Aslam. and Khizer H. K. 2018. Brackish water desalination using solar desalinationpannel. Curr. Inves. Agri. Curr. Res. 3 (1); 1-5.

[18] Dev Rahul and Tiwari GN, 2009. Characteristic equation of a passive solar still. Desalination 245 (1-3): 246-265.

[19] Ullah M. A., A.. Ali, M. Aslam and Khizer H. K, 2018. Effect of Temperature and Intake Flow Rate on the discharge of treated water during whole year. Int. J. of Res. Studies in Biosci. 6 (4); 14-17.

[20] Ullah M. A., A. Ali, M. Aslam A. Ullah and B. Lal, 2018. Reclamation of saline water through solar desalinization process under Arid/Semi-Arid of Thar at Umerkot District, Sindh, Pakistan. Int. J. of Advanced Res. in Chemical Sci. 5 (5); 1-7.

[21] Ullah M. A., A. Ali, M. Aslam A. Ullah and S. H. Ullah, 2018. Conversion of brackish water with solar desalinization technique in coastal belt of Lasbella Gadhani, Balochistan, Pakistan”. Acta Scientific Nutritional Health 2 (7); 64-68. 